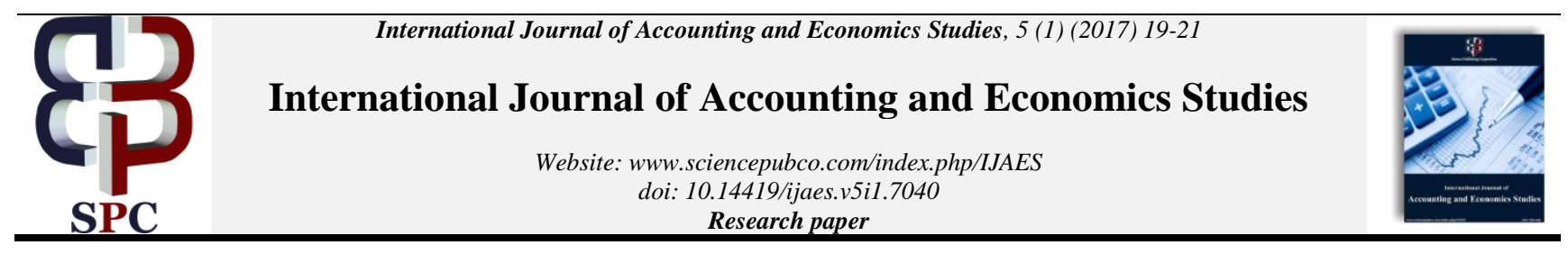

\title{
The impact of taxation on economic growth in India : A disaggregated approach using the ARDL bounds test to co-integration
}

\author{
Subramanya Venkataraman ${ }^{1 *}$, Arabi Urmi ${ }^{2}$ \\ ${ }^{1}$ Research Scholar, Department of Economics, Mangalore University, Mangalagangotri - 574119, Karnataka State, India \\ ${ }^{2}$ Professor and Research Guide, Department of Economics, Mangalore University, Mangalagangotri-574119, Karnataka State, India
}

*Corresponding author E-mail: subbu.paduvary@gmail.com

\begin{abstract}
Most Governments in the world are striving to attain long term growth and economic development with taxation as one of the major tools. However, it is necessary to know which components of tax are to be targeted in order to attain economic growth. This study therefore disaggregated the various components of direct and indirect taxes and investigated their effects on Economic Growth in India using time series data from 1977-2015 and the ARDL Bounds test approach to co-integration. The study found that in the long run, among the components of direct taxes, personal income tax had no impact on economic growth whiles corporate income tax had a positive statistically significant impact on economic growth. Further on the indirect taxes, the study found that in the long run, whiles excise duty had no statistically significant impact on economic growth, customs duty had a positive statistically significant impact. The study therefore concluded that policy makers must be circumspect in targeting which tax components to be used as tools in influencing long term economic growth and economic development.
\end{abstract}

Keywords: ARDL; Economic Growth; India; Taxation.

\section{Introduction}

One of the major sources of revenue used by Governments all over the world is taxes. Thus Governments collect taxes in order to carry out various activities that would better the livelihoods of their citizens by attaining long term economic growth which is a sine qua non for economic development. Therefore given that attaining long term economic growth is one of the major macroeconomic goals of most Governments all over the world, in using taxes as tools to stimulate long term growth, it is important to know which tax components should be targeted.

In the case of India, it is very important because fiscal challenges in the form of deficits have necessitated various reforms which include the Fiscal Responsibility and Budget Management (FRBM) Act 2003 which had reducing revenue deficit by $0.5 \%$ of GDP annually as one of its targets with full elimination to be attained by 2008-09. However, amendments in 2012 targeted ousting effective revenue deficit by March 31st, 2015 which vide the Finance Act 2015, has been extended to March 2018 (Rustagi, 2016).

Thus by targeting the elimination of revenue deficit in order to achieve long term economic growth, it is very essential to know which revenue sources to be targeted. Specifically, since taxes are one of the major sources of revenue to Governments all over the world, it is imperative to know which tax components are relevant to attaining long term economic growth and hence ousting revenue deficit.
This study therefore, disaggregated the various components of direct and indirect taxes and studied their individual impacts on Economic Growth in India.

\section{Literature review}

Theoretically, high taxes can be seen to be negative for investment, employment and economic growth (Poirson, 2006). High tax rates may also help generate growth in the "shadow economy," carrying costs with regards to foregone tax receipts and lower productivity growth (Farrel, 2004; Schneider\& Klinglmair, 2004 as cited in Poirson, 2006). It is therefore not surprising that Poirson (2006) contends that the empirical evidence is mixed. On the empirical literature, Magu (2013) in Kenya found increases in VAT to have a positive effect on economic growth. Ekpung and Wilfred (2014) revealed an inverse relationship between corporate and personal income taxes on one hand and economic growth and investment on another hand in Nigeria. Ojong, Anthony and Arikpo (2016) found significant relationships between growth and nonoil revenue and petroleum profit tax with the relationship between company tax and growth being insignificant in Nigeria. Poirson (2006) revealed that recent reforms in India would improve tax productivity and decrease the marginal tax burden and distortions created by tax. However, high marginal tax rates would confront firms with borrowing challenges or firms who are dependent on internal sources of funds. Oshoke (2016) in Nigeria found value added tax to have a negative significant impact on real GDP. Further, past excise and custom duty was found to have a negative and feebly significant effect on real GDP. The findings of Ahmad, Sial and Ahmad (2016) in Pakistan suggest that reducing indirect 
taxes and raising direct taxes would better ensure growth. Chaurasia, Singh, and Sen (2016) concluded that goods and services tax (GST) would be helpful to GDP growth by more than two Percent in India.

However, specifically on the studies on India, Chaurasia, Singh and Sen (2016) just used descriptive analysis and Poirson (2006) also used a relatively older data as compared to the one used by this paper which covered more FRBM/post FRBM period and hence would better inform the current impact of taxation on growth. Aside the above, the scanty amount of research conducted on tax and growth in India further reinvigorated the need for our study. Further, we used a more relatively current data to investigate how various components of taxes impacted economic growth in India.

\section{Methods}

\subsection{Data}

The study used Indian time series data obtained from the Reserve Bank of India (RBI) for the period 1977-2015 to attain its objective.

\subsection{Empirical estimation techniques}

We employed the Augmented Dickey Fuller and the Philips Perron tests for unit root to examine the stationarity of variables in order to curb spurious regression since literature has proved that most time series variables are non-stationary. After confirming that none of our variables was integrated of order 2 (I(2)), we moved on with the Autoregressive Distributed Lag (ARDL) model in order to investigate the short run and long run impact of the various components of direct and indirect taxes on economic growth in India. We therefore specified our empirical model of estimation as below:

$$
\mathrm{GDP}_{\mathrm{t}}=\emptyset_{0}+\emptyset_{1} \mathrm{PIT}_{\mathrm{t}}+\emptyset_{2} \mathrm{CIT}_{\mathrm{t}}+\emptyset_{3} \mathrm{TE}_{\mathrm{t}}+\emptyset_{4} \mathrm{dummy}_{\mathrm{t}}+\mu_{\mathrm{t},}(1)
$$

Equation 1 shows the impact of various components of direct tax on economic growth where, GDP is the economic growth indicator, PIT is personal income tax, CIT is corporate income tax, TE is total expenditure, and the dummy variable was coded as 0 for pre FRBM period and 1 for FRBM/post FRBM period and $\mu$ is random error term. All variables were in logarithmic forms except the dummy variable. We therefore re-specified (1) within the ARDL framework in a conditional error correction form to find out the long run relationship between the components of direct tax and economic growth in India as follows:

$$
\begin{aligned}
& \Delta \mathrm{GDP}_{\mathrm{t}}=\gamma+\sum_{\mathrm{i}=1}^{\mathrm{x}} \mho \Delta \mathrm{GDP}_{\mathrm{t}-\mathrm{i}} \\
& +\sum_{\mathrm{i}=0}^{\mathrm{x}} \Phi_{\mathrm{m}} \Delta \mathrm{M}_{\mathrm{t}-\mathrm{i}}+\delta_{1} \mathrm{GDP}_{\mathrm{t}-1}+\delta_{\mathrm{m}} \mathrm{M}_{\mathrm{t}-1}+\mu_{\mathrm{t}},
\end{aligned}
$$

GDP is as defined already, $\mathrm{m}$ is the number of regressors, $\Delta$ is a difference operator, $\mathrm{x}$ is the optimal lag length, $\mathrm{M}$ is a vector of observations of independent variables, $\gamma$ is intercept and $\mu_{t}$ is the error term.

For the model on the impact of various components of indirect taxes on economic growth in India, we have

$$
\begin{aligned}
& \mathrm{GDP}_{\mathrm{t}}=\emptyset_{0}+\emptyset_{1} \mathrm{EXD}_{\mathrm{t}}+\emptyset_{2} \mathrm{CSD}_{\mathrm{t}} \\
& +\emptyset_{3} \mathrm{TE}_{\mathrm{t}}+\emptyset_{4} \text { dummy }_{\mathrm{t}}+\mu_{\mathrm{t}},
\end{aligned}
$$

Equation 3 shows the impact of various components of indirect tax on economic growth where, EXD is excise duty, CSD is custom duty and GDP, TE and dummy are as already defined with $\mu$ being the random error term. All variables were in logarithmic forms except the dummy variable. We therefore re-specified (3) within the ARDL framework in a conditional error correction form to find out the long run relationship between the components of Indirect tax and economic Growth in India as follows:

$\Delta \mathrm{GDP}_{\mathrm{t}}=\gamma+\sum_{\mathrm{i}=1}^{\mathrm{x}} \mho \Delta \mathrm{GDP}_{\mathrm{t}-\mathrm{i}}+\sum_{\mathrm{i}=0}^{\mathrm{x}} \Phi_{\mathrm{m}} \Delta \mathrm{M}_{\mathrm{t}-\mathrm{i}}$

$+\delta_{1} \mathrm{GDP}_{\mathrm{t}-1}+\delta_{\mathrm{m}} \mathrm{M}_{\mathrm{t}-1}+\mu_{\mathrm{t}}$

All notations are as already defined.

\section{Results and discussion}

\subsection{Unit root results}

Table 1: Augmented Dickey-Fuller (ADF) and Philips Perron (PP) Tests for Unit Root

\begin{tabular}{lllll}
\hline \multirow{2}{*}{ Variable } & $\begin{array}{l}\text { Log Levels } \\
\text { ADF Test }\end{array}$ & PP Test & \multicolumn{2}{l}{ First Difference } \\
& t-statistic & Adj.t-statistic & t-Statistic & PP Test \\
& Adj.t-statistic \\
\hline LNTE & -1.294170 & -1.294170 & $-6.441583^{\mathrm{a}}$ & $-6.441220^{\mathrm{a}}$ \\
LNPIT & -0.194031 & -0.036392 & $-7.735144^{\mathrm{a}}$ & $-7.905591^{\mathrm{a}}$ \\
& & & & \\
LNCIT & -0.055833 & -0.055833 & $-5.791476^{\mathrm{a}}$ & $-5.798090^{\mathrm{a}}$ \\
LNEXD & -0.757260 & -0.759828 & $-6.362916^{\mathrm{a}}$ & $-6.362723^{\mathrm{a}}$ \\
LNCSD & -2.309990 & -2.312321 & $-5.256015^{\mathrm{a}}$ & $-5.256015^{\mathrm{a}}$ \\
LNGDP & 0.315286 & -0.232675 & $-4.351503^{\mathrm{a}}$ & $-4.420688^{\mathrm{a}}$ \\
\hline Source: Author'
\end{tabular}

Source: Author's computation from RBI data. Note: $a, b$, c denote significance at $1 \%, 5 \%$ and $10 \%$ level, respectively

From Table 1, it is evident that none of the variables was I(2) and hence we moved on with the ARDL co-integration technique since it is capable of dealing with whether all variables are $\mathrm{I}(0)$ or all are I(1) or a mixture of both.

\subsection{Cointegration results}

Table 2: ARDL Bounds Cointegration Results for the Components of Direct Tax Model F-Statistic = 5.286

\begin{tabular}{lll}
\hline K (no of regressors) & Percentage & Critical Values \\
\hline & & $\mathrm{I}(0) \mathrm{I}(1)$ \\
4 & $10 \%$ & 2.453 .52 \\
4 & $5 \%$ & 2.864 .01 \\
4 & $1 \%$ & 3.745 .06 \\
\hline
\end{tabular}

Source: Authors computation from RBI data.

Since the F-statistic (5.286) was above all the upper bound values at $10 \%, 5 \%$, and $1 \%$, we rejected the null hypothesis of no cointegration and hence proceeded with our ARDL model.

Table 3: ARDL Bounds Cointegration Results for the Components of Indirect Tax Model F $=4.191$

\begin{tabular}{lll}
\hline K (no of regressors) & Percentage & Critical Values \\
\hline & & $\mathrm{I}(0) \mathrm{I}(1)$ \\
4 & $10 \%$ & 2.453 .52 \\
4 & $5 \%$ & 2.864 .01 \\
\hline
\end{tabular}

Source: Author's computation from RBI data.

Since the F-statistic (4.191) was above the upper bound values at $10 \%$ and $5 \%$, we rejected the null hypothesis of no cointegration and hence proceeded with our ARDL model.

\subsection{Regression results}

Having established the absence of autocorrelation and heteroskedasticity using the Breusch-Godfrey LM Test and the BreuschPagan / Cook-Weisberg test respectively, the results from Table 4 showed that on the impact of components of direct tax on economic growth, the speed of adjustment (ECM (the error correction term)) in order to regain equilibrium after a shock was approximately $0.16 \%$ and also significant at one $1 \%$. Thus the pace of adjustment was comparatively slower and hence after a shock, it took some time for the model to restore back to equilibrium. 
From the long run results, personal income tax was insignificant. On corporate income tax, it was found that a $1 \%$ increase in corporate income tax led to a $0.61 \%$ increase in economic growth. This is contrary to the findings of Ekpung and Wilfred (2014) who found corporate income tax to have negative significant effect on economic growth in Nigeria and Ojong, Anthony and Arikpo (2016) who found Corporate Income Tax to have an insignificant relationship with economic growth in Nigeria. Also a $1 \%$ increase in total expenditure was found to lead to a $0.44 \%$ increase in economic growth in India. The FRBM/post FRBM dummy was however insignificant.

In the Short run results the study revealed that, a $1 \%$ increase in personal income tax led to a $0.03 \%$ fall in economic growth in India. Further, a $1 \%$ increase in corporate income tax was found to lead to a $0.1 \%$ increase in economic growth. Thus whiles corporate income tax had a positive impact on economic growth in the short run, personal income tax had a negative impact. Also a $1 \%$ increase in total expenditure was found to lead to a $0.07 \%$ increase in economic growth.

Table 4: Impact of Components of Direct Tax on Economic Growth

\begin{tabular}{llll}
\hline Variable & Coefficient & Standard Error & P-Value \\
\hline ECM & -.1561911 & .056723 & 0.010 \\
LNGDP & & & \\
Long Run & & & \\
LNPIT & -.1682327 & .1181826 & 0.164 \\
LNCIT & .6143684 & .18009 & 0.002 \\
LNTE & .4394761 & .1039793 & 0.000 \\
Dummy & .0206015 & .1328248 & 0.878 \\
Short Run & & & \\
LNPIT D1 & -.0262765 & .0117128 & 0.032 \\
LNCIT D1 & .0959589 & .0242989 & 0.000 \\
LNTE D1 & .0686423 & .0326305 & 0.043 \\
Dummy D1 & .0032178 & .0204215 & 0.876 \\
Constant & .6810464 & .221317 & 0.004 \\
\hline Sout & & &
\end{tabular}

Source: Author's computation from RBI data. Sample 1977-2015 and

Number of obs: 39

Breusch-Godfrey LM Test for Autocorrelation:

Ho: no serial correlation, chi2 $=0.689$ Prob $>$ chi $2=0.4065$

Breusch-Pagan / Cook-Weisberg test for heteroskedasticity:

Ho: Constant variance, chi2 $(1)=0.68$, Prob $>$ chi2 $=0.4085$

Table 5: Impact of Components of Indirect Tax on Economic Growth

\begin{tabular}{llll}
\hline Variable & Coefficient & Standard Error & P-Value \\
\hline ECM & .0946796 & .0345405 & 0.010 \\
LNGDP & & & \\
Long Run & .2184953 & .4098581 & 0.598 \\
LNEXD & .545567 & .2623829 & 0.047 \\
LNCSD & .2542928 & .3375385 & 0.457 \\
LNTE & .3618011 & .2561923 & 0.169 \\
Dummy & & & \\
Short Run & .0143347 & .037172 & 0.703 \\
LNEXD D1. & -.0916379 & .0441481 & 0.047 \\
LNEXD LD. & -.1148025 & .0373621 & 0.005 \\
LNEXD L2D. & -.0682739 & .0382602 & 0.085 \\
LNEXD L3D. & .0516541 & .0155843 & 0.002 \\
LNCSD D1. & .0240763 & .0358468 & 0.507 \\
LNTE D1. & .0342552 & .0224049 & 0.137 \\
Dummy & .4486834 & .1046286 & 0.000 \\
Constant & &
\end{tabular}

Source: Author's computation from RBI data. Sample 1977-2015 and

Number of obs: 39

Breusch-Godfrey LM Test for Autocorrelation:

Ho: no serial correlation, $\operatorname{chi} 2=1.991$ Prob $>$ chi $2=0.1582$

Breusch-Pagan / Cook-Weisberg test for heteroskedasticity:

Ho: Constant variance, chi2 $(1)=0.80$ Prob $>$ chi $2=0.3719$

The results were robust given the absence of autocorrelation and heteroskedasticity. Therefore from Table 5 above on the impact of components of indirect tax on economic growth, the speed of adjustment was approximately $0.09 \%$ and also significant at one $1 \%$. However, it was relatively slower and hence it means that after a shock, it took some time to restore back to equilibrium.

From the long run results, excise duty was statistically insignificant. Further, a $1 \%$ increase in customs duty was found to lead to a $0.55 \%$ increase in economic growth in India. Thus whiles excise duty had no significant impact on economic growth in the long run, customs duty had a statistically significant impact. However, both total expenditure and the FRBM/post FRBM dummy had positive coefficients but rather statistically insignificant.

In the Short run, excise duty was found to have a negative impact on economic growth in India. Also, the study revealed that a $1 \%$ increase in custom duty led to a $0.05 \%$ increase in economic growth. The results on excise duty and custom duty are respectively similar and contrary to the findings of Oshoke (2016) in Nigeria. Thus in the short run whiles custom duty had a positive impact on economic growth, excise duty had a negative impact. A similar scenario was seen above for personal income tax and corporate income tax.

\section{Conclusion}

It can be therefore be concluded that economic growth is susceptible to the kind of tax used and hence policy makers should pay attention to the kind of tax to be used, in the attempt to attain long term economic growth.

\section{References}

[1] Ahmad S, Sial MH \& Ahmad N (2016) Taxes and Economic Growth: an Empirical Analysis of Pakistan. European Journal of Business and Social Sciences, 5 (2), 16 - 29.

[2] Chaurasia P, Singh S, \& Sen PK (2016) Role of Good and Service Tax in the Growth of Indian economy. International Journal of Science Technology and Management, 5 (2).

[3] Ekpung EG \& Wilfred OW (2014) the Impact of Taxation on Investment and Economic Development in Nigeria. Academic Journa of Interdisciplinary $\quad$ Studies, 3 (4) https://doi.org/10.5901/ajis.2014.v3n4p209.

[4] Magu MC (2013) the Relationship between Government Revenue and Economic Growth in Kenya. Master of Business Administration Research Project, University of Nairobi.

[5] Ojong CM, Anthony O \& Arikpo OF (2016) the Impact of Tax Revenue on Economic Growth: Evidence from Nigeria. IOSR Journal of Economics and Finance, 7(1) I, 32-38. DOI: 10.9790/5933-07113238

[6] Oshoke AS (2016) The Impact of Indirect Tax Revenue on Economic Growth: the Nigeria experience. Igbinedion University Journal of Accounting, 2, 62-87.

[7] Poirson H (2006) The Tax System in India: Could Reform Spur Growth? IMF Working Paper, WP/06/93.

[8] Rustagi P (2016) Fiscal Responsibility and Budget Management (FRBM) Act. Indian Economic Service. Accessed on 23/11/2016 from:

http://www.arthapedia.in/index.php?title=Fiscal_Responsibility_an d_Budget_Management_(FRBM)_Act. 